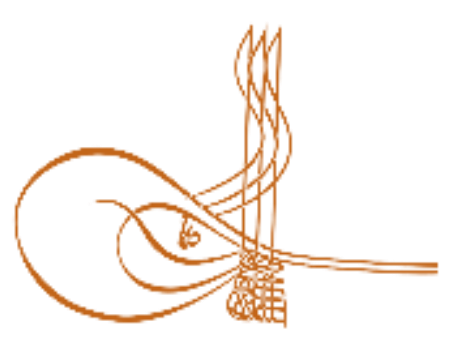

www.turkishstudies.net/turkishstudies
Turkish Studies

eISSN: $1308-2140$

Research Article / Araştırma Makalesi

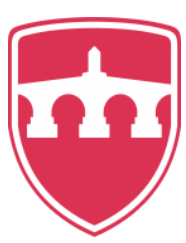

INTERNATIONAL

BALKAN

UNIVERSITY

Sponsored by IBU

\title{
Gelenekselden Günümüze Kukla Tiyatrosunda Kostüm
}

Costume from Traditional to Present Puppet Theater

\author{
Melahat Çevik*
}

\begin{abstract}
Puppets create a magical world with their historical and contemporary subjects. Contrary to popular belief, demonstrations were organized not only for children but also for adults. Puppet show for children predominates; because these presentations are educational as well as entertaining. Modern puppeteers can transform any object for the purpose of play, so they offer a wide range of applications. They also create cultural wealth while playing the puppet. Traditional puppets reflect the characteristics of almost every culture. For this reason, traditional stories, legends and tales were handled and staged all over the world and presented in traditional costume. This traditional aspect of the puppet; gives us an idea of where it comes from. It documents the cultural characteristics of the society in which it is located, its language, its essence, the puppet presentation. Texts; they are folk myths and have been moved from language to language, and today most of them are recorded. If the texts are anonymous, they provide information about the day, so they are quite rich historical documents. Each type of puppet has its own application methods. According to the necessity of puppet theaters; can use large and small scenes. If the game takes place with small puppets, a small stage or curtain is preferred. However, if a mixed play with human-sized puppets and actor is to be performed, the stage dimensions, puppet sizes and costume dimensions will also change accordingly. The aim of this study is to present the traditional puppet theater; stages of costume development and costume application methods are examined. Working method; will be made by comparison method on the past and present works.
\end{abstract}

Structured Abstract: An important element of the performing arts is the stage costume, and in the puppet theater we can see the distinctive aspects of design elements through traditional and present-day practices. The use of costumes in the performing arts has become an essential part of the stage today. Even if it is not shaped around the subject, the costume is designed for players to create unity on the stage and start the illusion.

Puppet is an interdisciplinary art object. These art objects can be found in every corner of the world with both modern and traditional elements. Since the early ages, people have been involved in social life; puppets have given place for both faith and play. For this reason, the period in which it was made and played; language, religion, clothing, economy, in short, deals with all aspects of life. Puppet theater cultural structure;

\footnotetext{
* Dr. Öğr. Üyesi, Van Yüzüncü Yıl Üniversitesi, Güzel Sanatlar Fakültesi, Sahne Sanatları Bölümü Asst. Prof. Dr., Van Yüzüncü Yll University, Faculty of Fine Arts, Department of Performing Arts ORCID 0000-0001-9195-8123

melahat.cevik@yyu.edu.tr

Cite as/ Atıf: Çevik, M. (2020). Gelenekselden günümüze kukla tiyatrosunda kostüm, Turkish Studies, 15(1), 93-104. https://dx.doi.org/10.29228/TurkishStudies.37353

Received/Geliş: 19 September/Eylül 2019

Accepted/Kabul: 25 February/Şubat 2020

Copyright (C) MDE, Turkey

Checked by plagiarism software

Published/Yayın: 29 February/Şubat 2020

CC BY-NC 4.0
} 
It is the art object that carries to the present day through animated figures. These sacred objects have been carefully preserved, especially in the ruins of ancient culture. Therefore, puppets of today carry elements from our daily life. There is always a place in our lives as a tutorial and game tool. In the Middle Ages, demonstrations were organized to spread church teachings and puppetry became an important tool in these demonstrations. We see shadow puppet presentations especially in the palace entertainment of the Ottoman period. Mobile communities have increased the diversity and subject of the species. From time to time, specific country-specific design elements and species characteristics have been moved beyond the limits. In this sense, shadow puppets were born in Asia and spread to Europe.

It is a type of art that expresses to all ages of all ages, but the perception of all ages can change. In this sense, puppet has design elements that can gather people of all ages in one denominator. The same puppet can be manipulated to many age groups by changing the subject and presentation format. Costume is an important element in puppet theater. Transferring acting to an object is more difficult than real acting. Therefore, costume has an important place in the transformation and manipulation process of the object. The object in question is transformed into costume, even if it is an ordinary object, not a puppet. It finds meaning in the competence of the player in the process of manipulating the conversion.

The process of designing professional puppet costumes requires special training. It should be remembered that it will serve dramatic action. As it progresses gradually, the subject-oriented anatomical characteristics of the puppet will be determined first. These anatomical features and puppet type; reveals the principles of costume necessity. So design elements as hand puppet drawstring puppet or shadow puppet are made as a result of certain criteria. In the light of this information, puppet costume sketches are prepared with due care. The sketches appear in the hands of a tailor or a different practitioner and continue with the same team spirit. During the costume application, it is necessary to pay attention to material and technical points. The main element is a costume, but there are some compulsory situations that are caused by gravity and physical rules. Costume and puppet weight should be balanced, the material must meet the stage requirement and should not contain any design elements that will interfere with the dramatic action. In other words, anatomical features and joints should not be obstructed by costume for movement. The overcoming of these difficulties by the manipulator, the player, depends on the practitioner's strict adherence to these rules in the workshop and design process.

Features attributed to the traditional puppet; Since it is a spiritual entity and an object of art, it has preserved its physical properties to the present day. This situation; puppet and costumes. Traditional costume and puppet types; archives have survived in museums and private collections. In spite of modernization, it is a very important feature that the traditional aspect is permanently conveyed by expressive objects.

Animation genres are quite common in the show business. Modern puppets come out of the fantastic world with extraordinary designs as described by today's people. The unlimited possibilities of technology provided a different playground and toys. Professional shows continue on television. In particular, interdisciplinary studies have carried the puppet to every part of life. Cinema-television has an important place in these disciplines. In today's world, puppet shows are presented in the world of television and every discipline brings its own materials and design elements. The necessity of fabric application, especially in costume, has disappeared.

Keywords: Stage design, Puppet, Costume,

Öz: Kuklalar tarihi ve güncel konularıyla günümüzde de büyülü bir dünya yaratıllar. Sanılanın aksine, sadece çocuklar için değil yetişkinler içinde gösteriler düzenlenmiştir. Çocuklar için kukla gösterisi ağır basar; çünkü bu sunumlar eğlendirici olduğu kadar öğreticidir de. Modern kuklacılar her nesneyi oyun amacı için dönüştürebilirler, bu nedenle uygulamada geniş bir yelpaze sunmuşlardır. Ayrıca kuklayı oynatırken kültürel zenginlikte oluştururlar. Geleneksel kuklalar hemen hemen her kültürün özelliklerini yansıtır. Bu nedenle dünyanın her yerinde geleneksel hikâyeler, efsaneler, masallar ele alınıp sahnelenmiş ve bunlar geleneksel kostümle sunulmuştur. Kuklanın bu geleneksel yanı; çıktığı yer hakkında bize muhakkak bir fikir verir. Bulunduğu toplumun görünüşü, dili gibi kültürel özelliklerini, kısaca özünü, kukla sunumu belgeler. Metinler; halk söylenceleridir ve dilden dile taşınmıştır, günümüzde ise çoğu kayıt altına alınmıştır. Eğer metinler anonim ise, o gün hakkında bilgi verir, bu nedenle oldukça zengin tarihi belgelerdir. Her kukla türünün kendine özgü uygulama yöntemleri vardır. Kukla tiyatroları gerekliliğine göre; büyük ve küçük

Turkish Studies, 15(1) 
sahneleri kullanabilmektedir. Eğer oyun küçük kuklalarla gerçekleşiyorsa küçük sahne ya da perde tercih edilir. Ancak insan boyutlu kuklalar ve oyuncuyla karma bir oyun sergilenecekse, sahne boyutları, kukla boyutları ve kostüm boyutları da buna bağlı değişecektir. Çalışmanın amacı gelenekselden günümüze kukla tiyatrosunda; kostüm gelişim aşamaları ve kostüm uygulama yöntemleri irdelenmiştir. Çalışma yöntemi; geçmiş ve günümüz eserleri üzerine kıyaslama yöntemiyle yapılacaktır.

Anahtar Kelimeler: Sahne Tasarımı, Kukla, Kostüm

\section{Giriş}

İnsanoğlu var olduğu günden beri kuklaları yaşamına, çeşitli nedenlerle dahil etmiştir. Bu gerek inanç sistemlerine bağlı gerekse oyun amacıyla olmuştur. Aklın ve bilimin gelişimi kuklayı olması gereken yere birçok toplumda taşınmıştır, kukla gösterisi yegâne amacıdır. Günümüze gelindiğinde bu amaçla, çeşitli teknik ve uygulamalarla görürüz. Bir mekanizmaya bağlı nesne ve bu mekanizmayı hareket ettiren gizlenmiş bir kişi sayesinde kukla sunumu yapılır. Kukla oynatıcı kontrolü ve yerçekimi altında aksiyona sokulan teatral figür veya nesne'dir, manipülasyon teknikleri, fiziksel yasaları bilmek gerektirir. Oynatıcının değişimiyle; sunumda sesin ve hareketin özellikleri değişebilir. Kuklalar, gerek bu mekanizma (kukla) gerekse sunumun incelikleriyle masumluk ve saflığı temsil eder. Bu nedenle de, kişide genelde çocuklar için yapıldığ 1 kanısını uyandırmaktadır. Kuklalar yediden yetmişe herkesi kavrar, bunu yapabilmenin yolu derin yaşamsal deneyimlerdir.

"Kukla alanına daha derinlemesine nüfuz etmeye çalıştığımızda, bu konu... Sadece tarih değil, aynı zamanda estetik, psikoloji, pedagoji diğer bilim ve pratik gibi birçok alan ve disiplinlerinin uzun ve çeşitli öğütlerini içermektedir.” (Sechtlovi, Malik, Dvorak;1988:11)

Tarihsel süreçte geleneksel kukla tiyatrosu özellikle eğlencelerde ve kutlamalarda kullanılmış, ayrıca antik kültürlerden günümüze ritüel aracı olmuştur. Bu nedenle geleneksel yapı neredeyse bütün dünyada, önemle korunmuş günümüze taşınmıştır. Geleneksel halk kültürünü yaşatan gezici kuklacilar; sosyal ve kültürel paylaşımla bir iletişim gerçekleşmektedir. Bu nedenle geleneksel kuklacılar, kültürel iletişimin aracı olarak kabul edilmelidir. Karagöz ve Gölge Oyunu teknikleri Asya'dan Avrupa'ya çeşitli şekillerde görülür. Bu türü diğer kukla türlerinden özel kılan ayırıcı yönleri vardır. Aydınlatılmış bir perde üzerine görüntülerin ters 1şıkla yansıtılmasıyla oluşur.

Önceleri kukla türlerinde yaygın olarak Avrupa'da gezici grupların sunduğu gösteriler rağbet görmüştür. Bu gösterilerde geleneksel karakterler Punch, Petrushca, Kaspar, İbiş, Karagöz gibi her toplumun kendi kültürel yapısında yer alan karakterler üzerinden konular aktarılmıştır. Konu: diğer karakterler ve tipler arasında etkileşimler bu ana karakterin çatışmaları ile ilerler. Konu ilerledikçe karakterlerin toplumsal ilişkilerde rolü artar. Ve yaşadıkları ortamı ve kostümlerini; gerçek ya da fantastik nasıl olursa olsun, tutarlı bir şekilde sahnelemek gerekir.

Kukla tiyatronun bir dalı ve sahne üzerinde birçok bileșeni vardır. Kukla sahnesinin önemli özelliği sınırlandırılmış bir alana ihtiyaç duymasıdır. Bu bileşeler toplu sanat yapıtı olarak kurgulanır. Dekor, kostüm, 1şık, akustik ve müzik bu bileşenlerdir. Hepsi oldukça kapsamlı bir çalışmanın sonucu ve bir ekip ürünüdür. Bu ekip kukla yapım aşamasından sonrada işlevselliğini gösteri boyunca sürdürür. Birden çok uygulayıcıların dahil olacağı süreçler olabilir. Karmaşık uygulamalara gerektirecek kukla kostümü tasarlanmaktadır.

"Özellikle uzun vadede kuklaların kurulması çok zaman almaktadır ve en azından birkaç kuklacı bu iş için çalışmaktadır. Bunlardan biri ipliği bağlayıp ve konumunu kontrol ederken, diğeri aynı rocker (oynatma aparat1) kolunu tutar." (Becka, Havlik, Landra 1981:26)

Ancak bazı sunumlarda bu ekip tek kişiye indirgenebilir, bu durumda da, bütün uygulamalar gene aynı titizlikle yapılır. Çalışmanın gelişimi hem tutuma, hem maddi ölçütlere göre belirlenir. Gösterinin başarılı olmasının en büyük gerekliliği ise oynatıcının yetkinliğidir. 
Yaratıcılı̆ga, hızlı düşünme ve doğaçlama yeteneğine sahip olmalıdır. Oynatıcı burada edebi olan bir eseri veya sözlü bir çalışmayı dramatize ederken, karşılaşacağı sürpriz sonuçların üstesinden gelebilmelidir.

Kukla sahnelemenin, eğitici ve öğretici yönü önemlidir. "Kukla ve kukla tiyatrosunun çocuklarla ve gençlerle çalışmalarında kullanımı hem psikoloji hem de pedagoji açısından önemlidir. Bir kuklayı izlerken veya kukla performansında izleyici; aynı anda hem görsel hem de işitsel olarak eşzamanlı çoklu duyuları ile algılar. Kombine duyumlar daha yoğun etki etmekte ve uzun bir süre boyunca deneyimi yeniden yaratmaya ve hatırlamaya yardımcı olacak daha güçlü bir duygusal heyecan ortaya çıkarmaktadır. Bu nedenle kukla ve dokunsallığı hem okul öncesi hem de genç ergenlerin görüşünü etki ediyor; bu yaşlarda eğitim ve öğretimde bilginin temeli (hem görsellik, hem işitsellik)dir.” (Kovafíekova, Rödl, Smutna,...1978:5)

Görsellik öğesinde inandırıcılık sağlanır. Bu süreç izleyicinin oyuna dahil olması sonrasında aydınlanma sürecidir. İnandırıcılığı sağlamak için bütün öğeler aslına uygun tasarlanır ve oynatılır. Kukla tiyatrosunda her türlü nesne kukla olacağ 1 için giydirme potansiyeli ve malzeme çeşitliliği artar. En basit doğaçlama tasarım, örneğin bir çalı süpürge, deneyimli oynatıcı elinde giydirilince kuklaya dönüşür.

Bugün malzeme bakımından teknolojiye bağlı zengin bir yelpaze vardır. Orijinal kukla tasarımları incelendiğinde oldukça değerli kumaşların bu kukla yapımında kullanıldığı görülecektir. Malzemenin yapısı ve işleme yöntemleri; sanatsal yapıt olarak sanat nesnesine dönüşme sürecinde etkendir. Uygulama için doğru seçim gerektirir, bunu bilmek önemlidir. Kostüm tasarımında kumaş dışında birçok malzemenin kullanılabilirliği; tasarımcının yetisine bağlıdır. Sentetik kumaş türleri yanında doğada herhangi bir nesne ya da ürün kostümün temel malzemesi olabilir. Şöyle ki atık öğeler uygulanan çeşitli tekniklerle tasarımın hammaddesi olabilir. Kuklacı sadece bir nesneyi canlı bir figür haline dönüştürmez. Aynı zamanda ona yüklenmiş bir amaç etrafında çalışır ve kostümlerini bu amaçla tasarlar. Kukla gösteride artık yaşayan bir nesnedir. Yaşı, cinsiyeti, duyguları, korkuları, sevinçleri gibi yaşama belirtisi gösteren özellikleri olacaktır. Konu ele alındığında bireysel niteliklerin ana karakterlerde ince ayrıntısına kadar işlendiği görülecektir. Öyleyse tasarım özelliklede kostüm tasarım öğelerinde, öne çıkaran unsurların özenle yerleştirilmesi gerekir. Bu gösteride algı sürecine destek, tanımlayıcı görsel düzenlemelerdir.

Gösteri oluşması için bu süreç ve taraflar şarttır. Bu taraflar oynatıcı-kukla ve seyirci etkileşimidir. "Geniş kukla anlayışı; bir kukla tiyatrosu etkinliğinin altında yatan tüm olguları göz önünde bulundurma gerekliliğini ortaya koymaktadır. Burada "kukla tiyatrosu etkinliğ̈i” terimi, Joachim Fiebach'ın "teatral etkinliği” nin formülasyonu ve anlayışına dayanan kavramı olarak önerilmiştir, kuklalarla teatral aktivite veya kuklanın teatral kullanımı anlamında kullanılır. Fiebach, teatralliği kabaca "davranışı ve ifade şekli" olarak nitelendiriyor ve bu iletişimi teatral olarak nitelendiriyor. Böylece, kukla tiyatrosu kavramıyla, insanların özel davranışlarıyla karakterize edilen, bir kukla oyunu kavramını tanımlamak mümkün olacaktır. Bu kukla olarak adlandırılan ve dönüştürülen bazı eşyalara yöneliktir. Bu özel davranış, her şeyden önce, kuklanın sergilenmesiyle başlar; Burada hem kuklacı ile kuklaların doğrudan ele alınması hem de kuklaların alıcılar tarafından doğrudan görüntülenmesi içerir. İletişim sürecinin her iki tarafını da içermesi zorunludur. İzleyicilerin hayal gücünün etkisi olmadan gerçekleşmeyen, olaylara dayanmaktadır. Animasyon süreci; canlı etkisi yaratmak için, izleyiciyi ve izleyicinin hayal gücünü tetikler." (Taube;1995:21)

Seyircinin hayal gücünün devreye girebilmesi için tasarımcıların sahne bileşenlerinde illüzyonu yaratması gerekir. Bu nedenle kuklada kostüm tasarımı, her zaman yapılan işe boyut katar, giysi tasarımıyla kimlik kazandırılır. Elimize taktı̆̆ımız en basit şekliyle çorap ya da eldiven kukla; insan ve birçok figür yapmak için uygundur. Bir anda elimizi farklı bir canlıya dönüştürür.

"Kukla tiyatrosunu tiyatroda ayıran şey, canlı doğasında işlenen konulardır. Kuklanın 
sahnede gösterdiği konuyu; malzeme, işlev açısından ele alan kendine özgü tiyatronun bir türü olduğu biliyoruz. $\mathrm{Bu}$ anlamda yapılan tasarımda temasının ne olduğu, belirleyicidir. Ama bu nesne nasıl etkin kılınacak sorusu akla gelir. Nesnenin, izleyicinin algısına girmesi, canlı oyuncuyu temsil edebilmesi nasıl olur? Ve tabi ki; nesne ne zaman kukla olur?(...) Her şeyden önce, bir kuklanın ve yarı kuklanın ayırt edilmesi gerekir. Kukla, konuyu ele alan herhangi bir nesne olabilir; bir kukla oynamak için tasarlanan, uyarlanan, sergilenen ve taklit eden heykelsi varlıktır, amaçlı bir nesnedir. Böyle, bir "kukla" ele alındığında, muhtemel biçimlerinden biridir. Dahası kukla bir karakterdir." (Richter; 1997:299

Karakterler kişilik özelliklerini giyimlerine yansitırlar. Kukla tiyatrosunda kostüm tasarımı: tiyatro çalışmalarında olduğu gibi kostüm aşamalarının hemen hemen aynı süreçleri gerektirir. Bu çalışmada, dekor tasarımı ve kostüm tasarımları genelde aynı tasarımcı elinden çıkmaktadır. Büyük tiyatrolar için, yapılan büyük boyutlu çalışmalarda daha fazla zaman ve daha fazla emek gerektireceğinden farklı tutum sergilenebilmektedir. Tasarımcılar; belirli kriterlere göre kuklaları yaratmaktadırlar. Genelde kukla tasarımları küçük boyutlarda olacağından, kostümün aksesuar gibi bütün ayrıntıları da küçük tasarlanacaktır. Bu ölçeklendirme, sahne ölçüleriyle orantilidir.

Modern dönemle birlikte kuklaların hayatımıza farklı şekillerde dahil olduğunu görürüz. Televizyonun evlerimizde yeni yeni yaygınlaştığı dönemde Muppet Show; ekranlarımızda öğretici olmuştur.

"The Muppet Show, Muppet tabir edilen kuklalar ekseninde geliştirilmiş olan bir televizyon şovudur. 1976-1981 yılları arasında Jim Henson ve ekibi tarafından yapılmışlardır. Gösterinin yıldızı Susam Sokağı adlı çocuk programında da ana karakterdir. Kermit gösteri süresince sahneyi idare eden, konukları rahat ettirmeye çalışan, gösteri sanatçıları arasındaki problemleri halletmeye çalışan hareketli bir karakter olarak sunulmuştur. Zaman zaman absürt olarak kabul edilen parodilerle süslenen programda her bölümde bir konuk sanatçı bulunmaktadır." (wikipedia.org/muppet Show) 2019

$\mathrm{Bu}$ Show Muppet Show disiplinler arası bir çalışmanın ürünü olarak oldukça başarılı bulunmuştur. Bu nedenle günümüze gelene kadar çeşitli versiyonları yayınlanmıştır. Sinema olarak yakın tarihte gösterime girmiştir. Özellikle kukla gösterisinde postmodern bir yaklaşım olduğu, demografi açısından oldukça geniş bir kitleyi, küçük büyük herkesi kavradığı ve hala günümüzde önemini koruduğu bilinmelidir. Genel anlamda metinden ziyade, karakterler ve onlarla ilişkili gündelik hayatın içinde insanları (kukla) anlattıkları için, daha geniş bir kültürel yapı vardır. Gösteride kukla ve gerçek oyuncuların birlikte ancak karakterlerden çoğu kuklalar tarafından temsil edilir. Bu kuklalar oldukça insani vasıflarda tasarlanmıştır. Kostümlerine bakıldığında; bu kuklaların ilk gösteri yıllarında ki giyim modasını, insani özelliklerle yüklü, hayvan kuklalarla aktarılmıştır. Eldiven kukla Kurbağa Kermit ve Miss Piggy bu karakterlere en iyi örnektir. Kurbağa Kermit yeşil yakalı kurbağa kostümüyle özdeşmiş ve kostüm üzerine zaman zaman Show'daki rolüne uygun takım elbise kravat gibi ki ilaveler yapılmıştır. Miss Piggy ise; sarışın afet olarak oldukça süslü kadınsı domuzu canlandırır. İncileri ve dekolte elbisesiyle neredeyse özdeşleşmiştir.

Gene doksanlı y1llarda "Sesame Street" ya da ülkemizdeki adıyla "Susam Sokağı" ise dizi şeklinde hazırlanmış öğretici bir program ve kuklalarla karışık sunulmuştur. Bu program; giydirme kuklalar el kuklaları gibi birçok kukla türünü görmekte ve kostümlerini inceleme şans1 bulmaktayız. Edi İle Büdü el kuklalarıdır. "Minik Kuş" ve sokağın başında çöp tenekesinde hep gördüğümüz "Kırpık" karakteri zihnimizde yer eder. Bu kukalarda pelüş tüy ve çeşitli sentetik ve doğal kumaşı dikim teknikleriyle uygulanmış görmekteyiz.

"Susam Sokağı aslında başı başına bir akademik çalışma ürünüdür ve çok ciddi araştırmalar sonucu ortaya çıkıp yine çok ciddi araştırmalar sonucu yıllar içinde şekillenmiştir. öyle ki susam sokağı programı 1960'li yıllarda henüz dizayn aşamasındayken bu programı 
şekillendirmek için bir komite kurulmuştur ve komitenin başına Harvard'ın dünyaca unlu profesörlerinden Gerald Lesser getirilmiştir. Programın yapımcıllğını iki farklı ekip üstlenecektir ve bu ekiplerden biri televizyon yapımcıllğı konusunda uzmanlaşmış bir ekip, diğeri de çocuk gelişimi, öğrenme ilkeleri ve psikoloji konularında uzmanlaşmış, kendi alanlarında dünyanın uzman kabul ettiği akademisyenlerden oluşacaktır." (https://eksisozluk.com/susam-sokagi)2019

Susam sokağındaki pelüş kuklalar, büyük boyutlu giyilen kuklalardır. Bu tarz kukla kostümlerinde neler gereklidir. Oynatıcı ya da kostümü taşıyan kişinin bu anlamda eğitimli olması şarttır. Ayrıca kostümü tasarlayan kişinin birçok özelliği kostümde düşünmesi gerekir. Ama en başında gerek nefes gerekse bedensel rahatlık için hava sirkülasyonunu tasarlarken düşünmesi gerekir.

"Büyük boyutlu hayvan figürü olmak için, hayvan kostümleri kullanıcının vücudunun şeklini gizlemelidir ya da sonuç insanlaştırılmış bir hayvan olacaktır - bu yüzden çoğu durumda sıkı oturan bir tek parça streç giysi kullanımı tatmin edici değildir. Aynı şekilde, çok gerçekçi tamamen hayvan şekli de nadiren ikna edicidir. Dolayısıyla anatomik özelliklerinden çok hayvanın karakterini ve ruhunu ortaya çıkaran bir uyarlama veya stilize edilmiş kostüm tasarlanmalıdır. Kostüm, oyuncunun gerekli hareketleri yapmasına izin vermelidir, bu nedenle gerçek hayvanın bir miktar gözlemlenmesi yardımcı olacaktır ve tasarıma ilerlemeden önce, oyuncunun provalarını izlemek için zaman ayırmak önemlidir. Kostümün ağırlığının ve ısısının da akılda tutulması gerekir - bazen kostümün bir dereceye kadar (oyuncuyu) sınırlaması, sanatçının canlandırdığı şeyi hissetmesine yardımcı olabilir." (Jackson; 1993:105)

Sahneleme; birçok kurgulanan öğelerin birleşiminden oluşur. Konu, dönem, sosyal yapı ve kukla türü bunlara bağlı kuklaya yüklenecek vasıflar, kişilik gibi özellikler belirlenir. Kostüm tasarımında birçok ayrıntı ele alınır. Kukla türüne göre kostüm tasarlamak elzem bir durumdur. Kukla türleri genel bir bakışla şöyle sıralanmıştır:

"Kuklalar, oynatılış biçimine göre değişik türlere girer, değişik adlar alırlar. 1.Ayakları olmayan, alttan içine el sokularak oynatılan kukla, el kuklasıdır. 2. oynak eklem yerlerinden üstten iple hareket ettirilen kukla, ipli kuklası. 3. bir arabanın içinde, aşağıdan oynatılan kukla, araba kuklası; 4. bir sehpaya iliştirilen, sınırlı hareket olanağı olan ve yalnızca dans edebilen kukla, iskemle kuklası; 5. eklemleri alttan değneklerle hareket ettirilen kukla, değnekli kukla; 6. içine adam girerek oynatılan büyük kukla, dev kukla olarak sınıflandırılır" (Çalışlar; 1995: 383)

Malzemenin seçiminde ölçüsü, nasıl ve hangi malzeme kullanılacağı bu türlere bağlıdır. "Bir kukla için kostüm tasarlama ve yaratma süreci, normal bir insan için kostüm tasarlama ve yaratma süreci ile aynıdır. Her ikisinde de kişinin özel ölçülerini kullanan bir kalıp yapılır. Bu model daha sonra seçilen kumaş üzerinde aktarılır ve sonra nihai kostüm kesilir ve birleştirilir... Makine dikişi hassas bir sanattır. Makineyi nasıl kullanacağınızı ve çeşitli dikiş yöntemlerini bilmeniz ve bunları kullanma konusunda deneyim sahibi olmanız gerekir... Bunları yaparken kukla parçalarının ayarlanıp, değiştirilmesi gerektiğini daima aklınızda bulundurmalıyız... Kuklanın şeklini gösteren forma uygun bir kostüm oluşturmanız gerektiğinde, maliyet daha da zorlu olabilir. Kuklalar için çok hafif bir kostüm yaratmak gerekmektedir ve kukla ağır kostümlerde tam anlamıyla hareketini seyirciye aktaramaz. Bunun yanında alternatif olarak gevşek bir kostüm oluşturmak; animasyonu kolaylaştırabilir ancak bunda da kukla kumaşların içinde kaybolur, kostüm kuklanın hareketini gizleyebilir." (Walsh; 2019:99)

Kukla yapmadan önce plan yapmak gerekmektedir. Sahnede kullanılan her materyalin işlevselliği üzerine tartışmak yerinde olacaktır. Bunun için dikkat edilecek noktalar şunlardır.

"Bir kostümü planlamaya başlamadan önce, kuklanıza bakın ve onun özelliklerini ve kostüme ne gerekeceğini belirleyin. Farklı kukla türleri için farklı türlerde kostüm ve yapım tekniklerine ihtiyaç duyulacağını göreceksiniz. Kuklanızın ne kadar hareket etmesi gerekecek? Kostümünün veya bir parçasının gerçekten işlevsel mi? Bu kostüme ne kadar ihtiyacın var? $\mathrm{Bu}$ 
faktörler, sahip olduğunuz kukla türüyle birlikte - el / çubuk kukla gibi- kukla kostümünde tasarımcı ne yapması gerektiğine karar verecektir." (Lambeth; 2015:19)

Ayrıca kullanılacak malzemeye karar verirken iç mekân dış mekân gibi özellikleri sahne büyüklüğü, saklama koşulları ve maliyetini atlamamak gerekir. Çünkü bu ayrıntılar gösterinin devamı için önemlidir.

$\mathrm{Bu}$ bakımdan kuklalar aksiyona sokulma şekilleri ile yani oynatıcının oynatma mekanizmasına göre özel durumları gerektirir. Kuklanın teknik yönlerini düşünerek tasarım gerçekleşir.El kukaları için elin gireceği ölçüde kostümde ayrıntı tertip edilir. Bu nedenle bu mekanizmalar, kostümün bir parçasıyla saklanabilmelidir. Ayrıca değiştirilebilir olması için kuklanın ön ve arkası için açık bırakma gibi planlamalar yapılmalıdır. Bu aparatlar arka kısımda kostümle saklanabilmelidir. Geleneksel tiyatro türlerinde kostüm özenle çalışılır. Çünkü aynı zamanda bu tarihi belgeleyen bir eserdir. Japon kukla tiyatrosu "Buranku" özellikle kostümleriyle oldukça önemli bir yere sahiptir, kostümlerinde genelde değişiklik düşünülmez.

"Bunraku, Japonya'da 1700'lerden kalma bir kukla tiyatrosu türüdür. Adı aslında "edebiyat ve müzik" anlamına gelmektedir. Bunraku'nun üç bileşeni vardır: kuklalar, bir anlatıcı ve bir müzisyen. İnsan boyutunun üçte biri ila, üçte ikisi boyutunda olan kuklalar, sahnede tam olarak görünen üç operatör tarafından manipüle edilir. Bunlar, figürün baş ve sağ kolunu kontrol eden ana kuklacı, sol kolu çalıştıran ve destek sağlayan ikinci kuklacı ve ayakları çalıştıran ayak manipülatöründen oluşur. Kuklaların hareketli kafaları, gözleri, kaşları, ağzı ve parmakları olmasına rağmen, gövde yoktur, sadece bir çerçevenin üzerindeki geleneksel kıyafetler vardır. Kadın kuklaların kimonolarının uzunluğu nedeniyle ayakları yoktur; Bir kadının kıyafetlerini doğru hareket ettirerek bacakları ve ayakları varmış gibi görünmesini sağlamak ayak manipülatörünün işidir. Çok sayıda sahne ve özel efekt kullanılır.” (Granat, 2002, s.54)

Karagöz Hacivat gölge geleneksel kuklamız tasarlanırken oldukça meşakkatli bir süreç gerektirir. Bu geleneksel gölge kuklaların tasarımları iki boyutlu olduğundan, kostümü temsil eden boyama tekniklerini görürüz. Malezya gölge kukla tiyatrosu özellikle kültürel formlarıyla çok değerli mirasa sahiptir. Günümüzde formunu ve işlevini korumuş kukla evleri gösteri sunmaktadır.

"Wayang veya wayang kulit, Malezya, Endonezya'da ve Güneydoğu Asya'nın diğer bölgelerinde bulunan' kuklalar tarafindan oynatılan gölgeler; bazen insan karakterleriyle birlikte dramatik hikâyenin anlatıldığı tiyatrodur. Kökeni Ortaçağ döneminde Hinduizm‘in yayılması ve Güney Hindistan'dan Tholu bommalata adı verilen deriden kukla sanatlarının gelişine dayanmaktadır. Wayang kulit ve Endonezya'daki Wayangın en tanınmışlarını Unesco tarafindan 2003’te Sözlü ve Maddi Olmayan Mirasın Başyapıtı olarak belirlemiştir." (wikipedia.org/wiki/Wayang)

Özellikle vazgeçilmez kukla mirasımız Karagöz uygulama teknikleri de geleneksel tutumda aynı materyalle uygulama yapılmaktadır.

"Karagöz görüntüleri kalın derilerden, özellikle deve derisinden yapılır. Bunun daha önceleri düve derisi olduğu ileri sürülmektedir. Dana, sığır, manda derisinden, bu arada 1şık geçiren pürtüklü Ali Kurna kâğıdından yapıldığı olur. Bir deriden kol, boyun, yağlı olan karın altı çıktıktan sonra 30-40 tasvir kesilebilir. Deride aranan özellikler, saydamlaştırmaya yatkın, bir de sıcağa dayanıklı olması, eğilip bükülmemesidir. Deriyi işlemek için çeşitli işlemler vardır. Derinin kurutulması için Temmuz ve Ağustos aylan seçilir. Deri kepekli suda bırakılır, hamlatılır, güneşte tüyler çıkarılır, gerilir, tüy yerlerindeki deliklerin yok edilmesine çalışılır, camla derinin üzeri kazınır. Derinin koyu olanından çok açık renk olanı yeğ tutulur. Bundan sonra derinin üzerine kalıp konularak kalemle görüntünün resmi çizilir, deri bir thlamur kütüğü üzerine gerilir ve tığcılarda satılan nevrekân adlı sivri uçlu bıçakla bu çizgilerden kesilir; deri ters yüzünden yani hayvanın etine bitişik olan yüzünden kesilir, delikler ise öteki yüzden yapılır, kararan yerler bıçakla 
temizlenir, düz tahta üzerinde sıfır numara zımpara ile iki yanı temizlenir. Renklendirme için eskiden kök boyalar kullanılırdı, günümüzde renkli çini mürekkepleri kullanılmaktadır. Oynak, eklemli parçalar birbirine kiriş, kursak, tel veya naylon iple bağlanır. Değneklerin geçeceği delikler yuvarlak ikinci bir deri parçası dikilerek kalınca bir yuva haline getirilir." (And;1985:328)

$\mathrm{Bu}$ tarz gölge kuklalar, özel ve diğer kukla türlerinden malzeme, uygulama yöntemleriyle ayrılır. Geleneksel olarak kukla türümüzün başında yer alır. Geleneksel kukla kostümünde geleneksel bir tavır sergilenecekse, tanımlanmış renk doku ve tasarıma bağlı kalınması önemlidir. Metin geleneksel olacağından sunumu yapan oynatıcıların buna bağlı kalacağ 1 neredeyse kesindir, ancak yeni arayışlar da olabilir ve tasarımsal öğeler ise günün malzemesini irdelemeyi getirir. Çağdaş materyal eklemeleriyle ya da sadece çağdaş tasarım öğeleriyle mevcut kukla tiyatrosu metinlerini sunmayı amaçlayan gruplar vardır. Metinin gerekliliği konusunda bugün bir kıstas yoktur, çok sayıda kukla oyunu metinsiz temsil edilebilmektedir. Bilindik metinler ağızdan ağıza şekillenirken, gelenekselleşmiş kişilerin maceraları anlatılır. Toplumlar kendi kahramanlarını yaratırlar. Bu kahramanlar ve karakterler kukla tiyatrosunda çoğunlukla komik karaktere dönüşür.

"Kişilerin dış görünüşleri, fizik özellikleri önemlidir. Bunun başında giyim kuşam gelir. Oyunlarda belli kişiler hep belirli biçimlerde giyinirler. Bu kılık, giyim kuşam, kişinin geldiği yerin, toplumsal sınıfının, yetiştiği yerin yöresel özelliklerini taşır. Ayrıca o kişinin alışkanlıklarını, uğraşını, özelliklerini de belirtir. Sarhoşun elinde içki şişesi, Tuzsuz'un elinde bıçak, Tiryaki'nin elinde afyon çubuğu, Kabadayı'nın elinde tabanca, Kastamonulunun elinde balta, Laz'ın elinde kemençe bulunur. Kişileri tanıtıcı belirtkeler arasında her kişinin kendine özgü müzik, türkü ve dansları olduğu için, kişiler perdeye çıkarken giysilerinden, çalınan ezgiden, yaptıkları danstan veya okudukları şiirden tanınırlar.” (And;2004:62)

Amerika, Avrupa ve özellikle Almanya'da sayısızca kukla tiyatrosu vardır, modern ve klasik kukla gösteriler sunulmaktadır. Asırlık kukla evleri gösterilerine yüzyılı aşkın süredir devam etmektedirler. 18. yüzy1lda, operalar kuklalarla sunulmuştur. Bu kuklalar genelde Marionette dediğimiz ipli kuklalardır. İpler kuklada dokuz yere bölgesel hareketi sağlamak için bağlanır. Böylelikle figürünün hareketini daha hassaslaştırır. Baş, kollar, bacaklar, omurga, omuz bu önemli noktalardır.

"Bu kukla türü, bölgesel farklılıklara bağlı olarak tel veya ip kullanarak yukarıdan kontrol edilen bir kukladır. Kukla oynatıcısına marionettist denir. Marionette kuklalar oynatıcı tarafindan farklı tiyatro veya eğlence mekânlarında dikey veya yatay kontrol ipi ile izleyiciye gizlenmiş veya görünür halde oynatılır. Ayrıca filmlerde ve televizyonda da kullanılmıştır. İplerin tutturulması karakterine veya amacına göre değişir."

\section{(wikipedia.org/wiki/Marionette)}

İncelemek için Berlin kukla müzesi bu anlamda oldukça zengindir, özel kostümler günümüze kadar muhafaza edilmiştir. Bu müzede gerçek boyutlarda hayvan figürleri mekanik, metal kukla aksamları oynatma aparatları ve en önemlisi hemen hemen dünyanın her yerinden etnik kostümler incelenebilmektedir. 


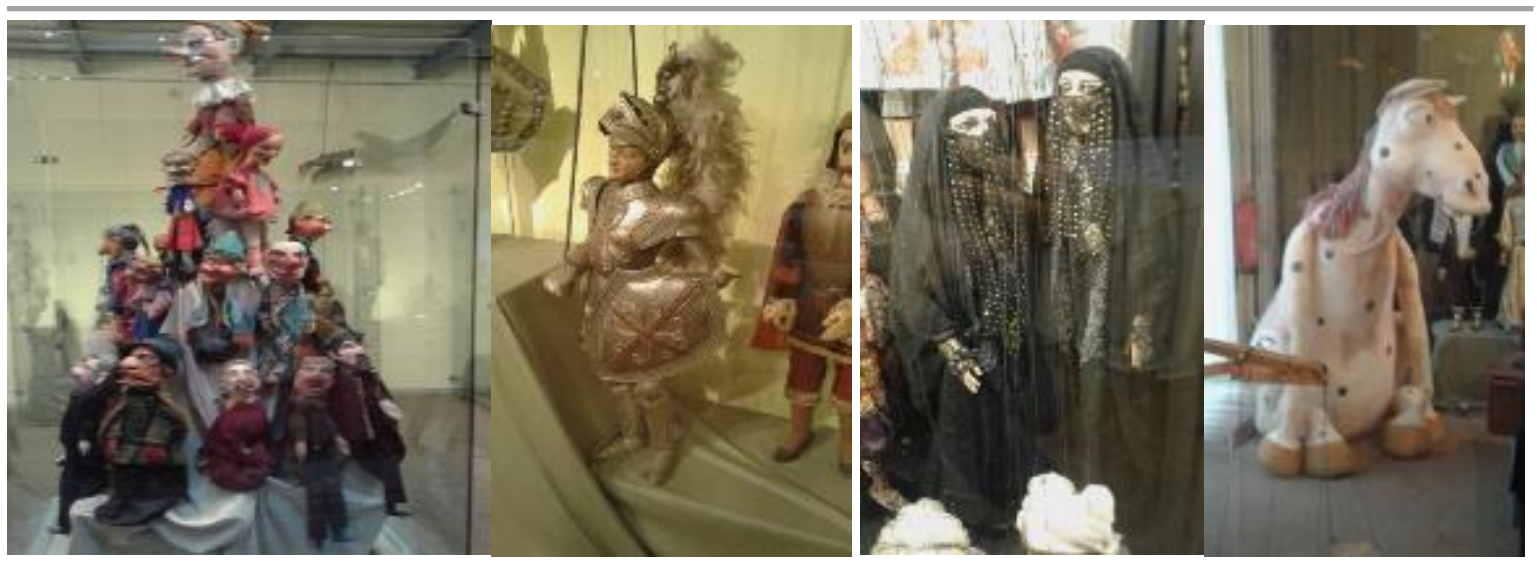

Resim 1: Berlin Kukla Müzesi, M.Çevik Arşivi.

Marionette kukla gösterilerinin sıra dışı özelliklerinden biri klasik müzik eserleriyle sunumlarının gerçekleşmesidir. Bu müzikler kukla tiyatrosunda kalıcılık öğesini, daha da pekiştirir. Mozart'ın bestesiyle "Sihirli Flüt" operası kukla sunumunda ormanda yaşayan canlıları ve fantastik yaratıkları sahne taşır. Kostümler ise; geleneksek kostüm ve fantastik kostüm bir arada uygulanmıştır. Böylelikle hem güncel hem de masalsı canlılara kostüm uygulaması yapılmıştır. Kostümler özenle, ayrıntılarıyla dikilmiştir. Bu kukalarda kumaş dışında; tüy dantel, şerit, pamuk, ponpon, püskül, kurdele, iplik, payet, pul, boncuk gibi birçok süsleme elemanı da kullanılmıştır.

Bunun yanında her ülkede çeşitli sunumları olmasına rağmen zihinlerde yer etmiş temel tasarımlar vardır. Pinokyo bilinen bir masal kahramanıdır ve kukla uygulamalarında aynı kostümle görürüz. Kostümler; kukla kimliğe vurgu yapmanın yanında dönemin giyim özelliklerini de yansıtır. Çünkü seyirci kodlanmış değerlerin beklentisindedir. Bu kukla kıyafetleri dönem çalışılacaksa, tarihi kitaplardan esinlenerek araştırma yapılabilir. Kostümün her sahne türü için genel olarak işlevi bellidir. Bu işlevselliği abartmak hem hareket kabiliyeti hem de gösterinin plastik öğe dağılımdaki dengesini bozar.

" $\mathrm{Bu}$, daha özgür, etkileyici bir tasarım için, oyunun karakterinin ve karakterlerinin görselleştirilmesini gerektirir... Şu noktayı hatırlamak her zaman önemlidir: Kıyafet fazlalı̆̆ kötüdür, çünkü giysiler oyunculuğu aşmamalıdır. Sadece onu engeller ve izleyiciyi oyunun dışına çok fazla taşır. Bizi oyunun ötesine götüren, görüşümüzü genişleten ve tarihsel anlayışı uyandıran büyüleyici bir iştir. Sonunda, halkın kıyafetlerini ve zamanlarını, taşıyıcılarının sosyal, manevi özellikleriyle ilişkilendirebileceğiz... Kostüm, sunumda doğal süreçlerin içindedir ve bize emanet edilen araçlardan sadece bir tanesidir, zihinsel bağlantıların netleştirilmesine yardımcı olmalıdır." ( Leonhard; 1955: 11)

Güncel gösterilere gelindiğinde ise tamamen tasarımcının hayal gücüne kalır. Yani kukla kostümü, kukladan bağımsız düşünülemez. Genellikle kukla mekanizması kostümle tasarlanacağından, tasarım bir bütün olarak çizilir. Sinemada kullanılan devasa kuklalar yeni yeni mekanizmaları gerektirse de kukla tiyatrosu mekanik çözümlemeleri zaten önceden belirlenmiştir. Bunun yanında devasa insan figürü dışında yaratık ya da hayvan figürleri de giydirilebilmektedir. Stopmotion ise yine sinema içinde animasyon tekniğiyle nesneleri ve özelliklede kuklaları kullanır. Burada çok fazla pozlama yöntemi gerekir, bu sunum direkt seyirciyle buluşmadığından düzenlenebilir ve aksiyon değiştirilebilir. Ayrıca kostümdeki değişiklik ve geçişler harekete göre ayrı ayrı dizayn edilir. Bu tür kukla konu ve tasarım çeşitliliği oldukça fazladır. Teknik gelişmelere bağlı sahnelendiğinden günümüz ve tarihsel her süreç ve her konu gösteriye yansitılır. Zamanın çok gerisine ve ilerisine uzanan zengin konu ve materyal çeşitliliği vardır. Buna bağlı kostüm uygulama teknikleri artar. Örneğin animasyon kuklaları oyun hamurundan yapıldığında giydirme 
işlemi genelde oyun hamuruyla tamamlanır. Hamura desen verme; baskı yöntemi ve renk uygulamalı belirleyici olabilmektedir.

"Stop-motion animasyon bir film yapım tekniğidir; bir kuklanın veya nesnenin fotoğrafinı çekiyorsunuz, sonra biraz biçiyorsunuz ve başka bir fotoğraf daha çekiyorsunuz. Sonra tekrar kuklayı oynatıp ve başka bir fotoğraf çekiyorsunuz. Bu işlemi yüzlerce kez tekrarlayarak ve münferit fotoğrafları sırayla tekrar tekrar oynayarak, kukla veya nesnenin kendi kendine hareket ettiğini ve bunun inandırıcıllğını ortaya koyuyorsunuz. Günümüzde hikâyelerini anlatmak ve izleyicileri eğlendirmek için hayatlarının çoğunu bu işi yapmaya adayan insanlar vardır." (Priebe; 2007: xiii)

Kukla özel boyutlarda yapılır. Eğer insan boyutunda ve insan kostümlü çalışması bilinen uygulamalarla devam eder. Ancak bu boyutlandırma küçük olabilir haliyle uygulamadaki her ayrıntı küçülecektir. Yakaya takılacak bir çiçek elde tutulan bir mendil artık bu özel boyutu gerektirir. İnce zanaat çalışmaları büyük önem taşır.

"Kukla kostümleri için kullanılan malzemeler genel olarak yumuşak, esnek, ince dokulu ve küçük desenli (desen isteniyorsa) olmalıdır. Aslında, tüm bu açılardan ölçeklendirilmeli, böylece yaşamdaki figürleriyle karşılaştırılabilir... Çalışma ilerlerken baskı ve dikişler, kukla kostümlerinin yapımında son derece önemlidir. Çünkü düzgün basılmadıkça ve dikişler göze çarpmayan şekilde yapılmadıkça orantısız şekilde hacimli görünecektir. A $\breve{g}$, dantel, şifon veya yumuşak kadife kumaşlara yalnızca ince dikişli el dikişleri kullanmalıdır. Daha ağır malzemeler için dikiş makinesi paha biçilmez bir yardımcıdır. Kukla kostümleri aslında yapmaktan ziyade inşa edildiğinden, kabul edilen anlamda, materyalleri doğrudan figürün üzerine asmak, örtmek, sıkıştırmak ve dikmek şeklinde işinize devam edebileceksiniz. Bazen, modacıdan farklı olarak, çıplak kuklaya kostüm giydirmek için yapıştırıcılar bile kullanabilirsiniz.” (Beaton; 2001:78)

Kukla gösterisi yapacak ekip koordineli çalışmalıdır; bu çalışma aşama aşama ilerlemeli hiçbir uygulama birbirinden bağımsız yapılmamalıdır.

\section{Sonuç}

Tiyatronun gelişimi insanın neredeyse var olduğu günden beri devam eder ve tiyatroya paralel kukla tiyatrosu ritüel ve oyun kaynaklı, nesneler üzerinden gelişmektedir. Zaman içinde sahneleme öğelerini daha fazla gelişim sürecine dâhil etmiştir.

Kostüm tasarımı gösteride; genel çizgileriyle bir varlığı ya da nesneyi bir amaca uygun giydirmektir. Bu amaç doğrulusunda varlık ya da nesneye kazandırılmak istenen özellikler açığa çıkartılır. Bu görsel iletişime yol açacağından, algılayıcısıyla değer kazanır. Yani sanatsal nesne formunu, izleyiciyle buluştuktan sonra tamamlar. Kostüm tasarımları kendi içinde tasarımcı yetkinliğine göre farklı alanlara ayrılır. Sahne kostümü tasarlamayı özel kılan yan ise, konu (metin) odaklı tasarımların gerçekleşmesi, dramatik aksiyona hizmet etmesidir. Burada kostüme yansıtılacak özellikler; yaş, cinsiyet, kültürel yapı ve ruh hali gibi birçok ayrıntı insan odaklı düşünülmelidir. Metine ya da doğaçlamayla karakter ve tipler belirlenmiştir. Karakteri ve diğer kişileri tasarım öğeleriyle ayrı kılmak gerekir. Bu nedenle yapılacak kostümün dramatik tür özelliklerine göre, derin bir gözlem ve araştırma neticesinde yapılması zorunludur.

Geleneksel tasarımlardan günümüze bu manada çok yol kat edilmesi yanında, arşiv niteliği taşıyan yapıtların paha biçilmez özelliklerini araştıran, tasarım çalışmaları vardır. Sanat yönetmeninin bu gösterilerde rolü daha da fazladır.

İyi bir kukla tasarımcısının dikkat etmesi geren özellikler vardır. Kukla kostüm tasarımcısı; kostümünde kuklayı hareket ettirip, yürütüp, oturta bileceği tasarımları ortaya koymalıdır, yani fiziksel yasaları bilmelidir. Özellikle kuklanın hareketini sağlayan, bağlantı noktaları, eklemler kostüm tasarımı tarafindan engellenmemelidir. Sunumda; kukla kostümünün rengi anlatım dilinin önemli bir parçasıdır. Sahne 1şıklama özelliğine göre elde edilecek renk seçimi deneyimlenmelidir. 
Ayrıca kuklanın bedeninde kullanacağınız malzeme ile kostümde kullanacağınız renk ve doku uyumunu da göz ardı edilmemelidir. $\mathrm{Bu}$ mekanizmaya yüklenecek kostümün ağırlığı dengelenmelidir. Çünkü bu ağırlık aksiyonun değişmesine veya oluşmamasına yol açabilir, hareketi zorlaştırdığı gibi hantal görünüm kazandırır. Bütün bunların düzenli işlemesi, koordinasyon zamanına uyması gerekir. Bu süreçlerdeki aksilik gösteri zamanlamasını bozacaktır.

Eğer geleneksel bilinen kostüm tasarımı çalışılacaksa; güncellemek için yeni malzeme yeni doku ve yeni kukla materyali ile görüntünün sonucunu bilmek önemlidir. Her malzemenin taşıyıcılık özelliği ve akışkanlığı farklı olacaktır. Bugün daha çok kullanılan sentetik kumaş türlerinin dikim, bakım ve esneme özellikleri farklı farklıdır. Beraberinde birçok uygulama zorluğu ve maliyet düşüklüğ̈ getirebilir. Bu bilgiler ışığında elde edilmek istenen görüntünün orijinaline yakınlığı elde edilmeye çalışılmalıdır. Şöyle ki eski geleneksel yöntemle gölge kuklalar için; deri dışında farklı malzemeden oluşmuş etkili arayışlar kullanılabilmektedir.

Sahneleme temel amaçtır. Bu bakımdan sahne ölçüleriyle uygun olmalıdır. Her ne kadar boyut küçüldükçe işin zanaat kısmı zorlaşsa da aynı titizlik, bu sanata gönül veren profesyonellerce ortaya konmaktadır. Kukla: kostümü, makyajı ve aksesuarları ile tarih, zaman ve mekâna uygunluk gerektirir. Tarihsel kostümün aslına uygun tasarlanması beklentiler arasındadır.

Dikim aşamasına gelindiğinde ise gösteri türü ve bütçe gerekliliği sonucu değiştirebilir. Bazen insan boyutlarında kuklalara dikim yapılır. Yaygın olan boyutlarda kuklanın ölçüleri bir metre ve altı olarak yaklaşık insan boyutunun üçte ikisi ya da üçte biri olarak tasarlanır. Bu boyutlarda tasarımları uygulamanın daha kolay yolları da vardır. Yapıştırılarak, ya da değişik monte yollarıyla kuklalar giydirilebilir. Malzemesi ahşap, plastik ya da bez kuklalar; kostüm ve ilave aksesuarla örneğin saç, makyaj farklı bir karaktere dönüştürülebilmektedir. Kukla tasarımı yapmadan önce kuklanın oynatma biçimi ve boyutlarına bağl1, farklı teknik kostüm tasarımıyla giydirileceği bilinmelidir.

Kukla kostümü yapmak meşakkatli bir iştir. Sahne Sanatları bölümü, Sahne Tasarımı eğitimini aldıktan sonra, kukla kostümü için özel bir çalışma yapmak gerekir. Kukla sahne yapıtının; insan eliyle nesnelerle aktarılan hareket, jest ve ses olduğu, kostüm tasarımı yapılırken unutulmamalıdır. Kuklalarla çalışmak alan bilgisi gerektirir, bu alanın belirli yasaları ve eğitimi vardır. Her şeyden önce eğitim, usta çırak ilişkisisinde olmakta, tasarımsal öğeler belirlendikten sonra uygulama aşaması, farklı titizlik gerektirir. Bu nedenle temel terzilik öğretileri yanında bir kukla atölyesinde sürece dâhil olmak zorunluluktur.

\section{Kaynakça}

And M., (1985). Geleneksel Türk Tiyatrosu. İnk1lap Kitapevi.

And M., (2004). Başlangıcından 1983'e Türk Tiyatro Tarihi. İletişim Yayınları.

Sechtlovi Marie A Josef, Malik J., Dvorak J.V., (1988). Svet Loutek. Praha: Kruh Nakladatelství.

Beaton M. and L., (2001). The Complete Book of Marionettes. Dover Publications, Inc.

Becka K., Havlik V., Landra R. (1981). Praha: Priloha Csl Loutkare. Roc IV, PNS,

Cheralyn L. (2015). New York: Well-Dressed Puppet: A Guide to Creating Puppet Costumes, Taylor Francis Grup.

Çalışlar A. (1995) Tiyatro Ansiklopedisi. TC. Kült. Bak. Yayınları.

Granat D. (2002) China and Japan. Professyonial Books.

Jackson S. (1993) More Costumes for the Stage. New Amsterdam Books, Inc. 
Kovafiekova V., Rödl O., Smutna M., Svec J., Mikulova Ma., Svec Jino, (1978). Praktikum Loutkoveho Divadla Ucebnice Pro IA IV. Rocník Strednich Pedagogickjch Skol. Praha: Statní Pedagogicke Nakladatelství.

Leonhard P. (1955) Kleine Kostüm Kunde. Deutscher Theaterverlag.

Ludek R. (1997). Od Predmentu Kloutce Od Loutky K Divadlu. Ipos-Artama

Priebe Ken A. (2007). The Art of Stop-Motion Animation.Thomson Pup.

Taube G. (1995). Puppenspiel Als Kulturhistorisches Phänomen. Max Niemeyer Verlag.

Walsh C. (2019). Stop Motion Filmmaking: The Complete Guide to Fabrication and Animation, Blommsbory Academic.

https://tr.wikipedia.org/wiki/The_Muppet_Show 2019

https//tr eksisozluk.com/gelmis-gecmis-en-basarili-sosyal-deney-susam-sokagi 2019

https://tr.wikipedia.org/wiki/Wayang 2019

https://en.wikipedia.org/wiki/Marionette2019 